\title{
DOES FINANCIAL PERFORMANCE MODERATE THE EFFECT OF CEO CHARACTERISTICS AND STAKEHOLDER INFLUENCE ON CORPORATE SOCIAL RESPONSIBILITY IN INDONESIA?
}

\author{
Lidya Agustina ${ }^{1}$, Yvonne Augustine Sudibyo ${ }^{2}$ \\ ${ }^{1}$ Doctoral candidate in Trisakti University and Lecturer in Accounting Department, Maranatha \\ Christian University, Indonesia, \\ ${ }^{2}$ Lecturer in Economic and Business Faculty, Trisakti University, Indonesia
}

lidya_kho@yahoo.com ${ }^{1}$, yvonneags57@gmail.com ${ }^{2}$

Correspondence authors: yvonneags57@gmail.com

\begin{abstract}
This study aims to examine the effect of CEO characteristics and stakeholder involvement on CSR disclosure quality, with firm performance as a moderating variable. This study was conducted with the assumption that the analysis of human factors (in this case management) is often forgotten when analyzing CSR reporting. Thus, the upper echelon theory is used as the basis in this study. This study also provides a different measurement of CEO education, where CEO education is not only seen from the background of economic and business education, but also seen from the CSR certification followed by the CEO. The study's findings, based on data from Kompas-100 firms listed on the Indonesia Stock Exchange from 2018 to 2019, show that CEO tenure, CEO education, and stakeholder involvement all have a significant positive influence on CSR disclosure quality. However, CEO compensation has no effect on CSR disclosure quality. Furthermore, the firm's financial performance was proven to moderate the positive influence between CEO tenure and CEO education on the quality of the firm's CSR disclosure, but failed to moderate the effect of CEO compensation and stakeholder involvement on the quality of the firm's CSR disclosure.
\end{abstract}

Keywords. CEO characteristics; Stakeholder Influence; CSR Disclosure; Firm Financial Performance

\section{Introduction}

Based on global research conducted by KPMG in 2017, many countries in the world are making efforts to increase the level of CS reporting. Meanwhile, the trend to include non-financial reports in the annual report increased dramatically in 2017, which is around $78 \%$ of the world's top firms (G250) [1]. How about Indonesia? Based on observations made by the author on firms listed on the Indonesia Stock Exchange in 2018, only about 20-25\% of firms present CSR reports (as separate reports from financial reports) on the firm's website. Although the government and stakeholders encourage firms to disclose their CSR, there are still many firms that have not presented annual CSR reports on a regular basis. This is because companies usually only look at short-term aspects and ignore the impacts of their activities such as social and environmental impacts [2].

Disclosure of Corporate Social Responsibility (CSR) is considered as the main communication tool for firm stakeholders regarding CSR activities [3]. CSR activities carried out by the firm can demonstrate that the firm, in addition to its business activities, plays a role in assisting the government and the community through various CSR implementation programs. Therefore, CSR disclosure is regarded as a critical tool used by a public relations firm to 
communicate and build mutual understanding, manage potential conflicts, and provide legitimacy to stakeholders and society as a whole [4]. Therefore, it is very important to know management's perception of CSR in relation to the effectiveness and efficiency of the firm's CSR disclosure.

The literature study conducted by Adams (2002) explains that CSR disclosure is often associated with three things, firm characteristics (related to the firm's financial performance), general contextual factors (related to the country where the report is published, social and political factors, media pressure and stakeholders), and internal contextual factors (the firm chair and the CSR committee). [5] shows that relatively few studies have examined the impact of internal contextual factors on the level and nature of sustainability reporting. In line with Adams' statement, Adams, Baele, and Everaert (2012) also stated that the analysis of human factors (in this case management) is often forgotten when analyzing CSR reporting. This has triggered the development of studies in this field. Empirical studies in recent years have shown increasing interest in analyzing the relationship between CEO characteristics and CSR disclosure [7]-[17]. However, the results of previous studies still show mixed results.

The results of studies conducted by Jian and Lee (2015) and Malik et al. (2020) found a positive relationship between CEO compensation and CSR performance, while the research results of Rekker et al. (2014) showed a negative effect. Meanwhile, the results of previous studies have shown various influences on the relationship between CEO tenure and CSR performance. The results of Huang (2013) and Malik et al. (2020) show a positive relationship between CEO tenure and CSR performance, while the results of Chen et al. (2019) and Lewis et al. (2014) show a negative relationship, and the results of Oh et al. (2018) show that there is no relationship between CEO tenure and CSR performance. The results of previous studies also show mixed results regarding the relationship between CEO education and CSR performance. The results of Lewis et al. (2014) and Malik et al. (2020) show a positive relationship between CEO education and CSR performance, while the results of Sun and Rakhman (2013) show that there is no relationship between CEO education and CSR performance. Based on this, the CEO characteristic variable needs to be investigated further in order to generalize the results of previous studies. This is also in line with the statement of Li et al. (2018) who argue that more research on the role of CEOs in CSR disclosure is needed.

Stakeholders are individuals, groups, or organizations who have the same interest in a particular organization [29]. Without the support of stakeholders, the firm cannot run its business properly [30]. The firm seeks to provide benefits to stakeholders by meeting sustainable development goals [31]. Therefore, stakeholders also have the same interests as the firm. Assuming stakeholders have moral responsibilities and the same moral goals, firms must demonstrate that they are acting to fulfill the moral responsibilities of stakeholders by disclosing their sustainability activities in sustainability reports [32] Research results also show that the pressure exerted by stakeholders demands high quality sustainability reports [33]. Based on this, the involvement of stakeholders (stakeholder influence) can affect the quality of the firm's CSR disclosure. In line with this, Rashid et al. (2020) stated that the role of strong stakeholders in CSR disclosure is still an interesting area for further research.

This study contributes to the existing literature in terms of human aspect as a focus of study. Because the study focuses on the characteristics of the firm's CEO, it emphasizes the human aspect, where business activities are driven by humans, as well as strategic decision making. Analysis of human factors (in this case the CEO) is often forgotten when analyzing the determinants of CSR disclosure. In addition, this study also provides different measurements related to CEO education, where researchers not only use the CEO's educational background, but also see whether the CEO obtained certification in the field of CSR or not. Thus, the results 
of this study can provide input for regulators, in particular providing input on CEO education. Furthermore, this study not only examines the direct relationship between CEO characteristics and stakeholder influence on CSR disclosure quality, but this study also examines how the firm's financial performance has the potential to affect this relationship. Thus, the findings contribute to the existing literature by providing new evidence.

\section{Theoretical Background Upper Echelon Theory}

Upper echelon theory (UET), which is widely used in the behavioral literature, including the domains of psychology and finance, appears to be suitable for studying individual beliefs, values, and behavior [41]. Upper echelon theory is "based on the assumption that business actors' behavior is rationally limited. Individual cognitive characteristics and values dominate the decisions of top management members with a major influence on second-tier managers and other employees" [42]. According to this theory, some observable personal attributes can inhibit/trigger the decision-making process, including CSR decisions [8]. In addition, Organizational outcomes resulting from strategic decisions and effectiveness are a reflection of leadership characteristics such as age, functional background, tenure, socioeconomic roots, education, and financial position, all of which shape leaders' values and cognitive abilities [41]. Thus, the characteristics of the CEO in this study that are related to the upper echelon theory consist of CEO compensation, CEO tenure, and CEO education.

Previous research has found that longer CEO tenure leads to more work experience, which allows CEOs to make better strategic decisions about CSR disclosure (Kruger, 2009). Furthermore, when it comes to the relationship between CEO compensation and CSR performance, CEO compensation in the form of equity shares (options) [14], as well as longterm payments [42] [43] can result in an increase in CSR performance. Furthermore, highly educated CEOs may prove to be better decision makers, as they are exposed to better knowledge and have an open-minded approach [41].

\section{Legitimacy Theory}

According Gray et al. (1995), legitimacy theory is "a condition in which a firm's value system is in line with the value system of a larger social system, of which the firm is a part. When there is a difference between the two value systems, then a threat to the firm's legitimacy will arise".

According to Deegan (2002), one of the factors motivating firms to disclose their social and environmental performance is the desire to legitimize the organization's operations. This shows that the firm wants its existence to be accepted by the community. Therefore, the firm needs to carry out activities that have the support of the community so that the firm's sustainability can be maintained.

This is consistent with the findings of [45], which show that firms that disclose their social performance have an impact on social values in the firm's operating environment. This is because legitimacy is influenced by culture, different interpretations of society, political system, and government ideology.

Stakeholders are individuals, groups, or organizations who have the same interest in a particular organization [29]. Without the support of stakeholders, the firm cannot run its business properly [30]. Assuming stakeholders have moral responsibilities and the same moral goals, firms must demonstrate that they are acting to fulfill the moral responsibilities of stakeholders by disclosing their sustainability activities in sustainability reports [32]. 


\section{Hypothesis Development \\ CEO Tenure on CSR disclosure quality}

Resource-based theory [50] assumes that "a longer CEO tenure is associated with better CSR". This is because CEOs have acquired more industry and firm-specific knowledge as a key requirement for the success of CSR activities. In line with this theory, the longer time a manager spends in the office dealing with office tasks/challenges, the more experienced and knowledgeable they tend to be [8].

Kesner (1988) reports that "directors need a minimum of three to five years, and sometimes more, to understand an organization's strategies and processes, in order to have a positive influence on its performance. The average tenure on the board can be explained by a number of factors, including events related to the organization's management and decisions by the directors themselves". The results of previous studies show that there is a positive influence between CEO tenure and CSR disclosure [8], [52]. Based on this description, the study proposes that more experienced CEOs are more aware of CSR practices and disclosures, regardless of whether they serve legitimate purposes or may support a stakeholder perspective.

hypothesis 1 (H1a): CEO Tenure has a positive effect on CSR disclosure quality.

\section{CEO Compensation on CSR disclosure quality}

Monetary and non-monetary incentives can play an important role in a person's decision choices. The CEO who is the driving force of the firm's strategic direction is a key official whose monetary and non-monetary interests can influence his decisions regarding CSR [8]. In line with this opinion, stocks increase CEO risk aversion. CEO shareholders will attempt to reduce potential risks to firm performance and share prices by avoiding irresponsible and socially unethical business decisions, while also attempting to accumulate moral capital by pursuing profitable and socially ethical activities [14]. The results of previous studies document that CEO compensation has a positive effect on CSR disclosure [8], [14]. Based on this description, the following hypothesis can be formulated:

hypothesis 1 (H1b): CEO compensation has a positive effect on CSR disclosure quality.

\section{CEO Education on CSR disclosure quality}

Highly educated CEOs may prove to be better decision makers, as they are exposed to better knowledge and have an open-minded approach [41]. Increased CEO education (e.g., with a master's or PhD degree, particularly in a CSR-related discipline) is also associated with increased reliance on stakeholder demands and CSR activities. This can be justified by the resource-based theory developed by Hart (1995). Other schools of thought, however, believe that, with the exception of MS and MBA degrees, other degrees have no effect on a firm's CSR performance, and that only specific education can affect CSR performance [52]. The results of [22] stated that managers with an MBA degree had a positive effect and a lawyer's degree had a negative effect on participation in carbon disclosure projects. Based on this description, the following hypothesis can be formulated:

hypothesis 1 (H1c): CEO Education has a positive effect on CSR disclosure quality.

\subsubsection{Stakeholder Influence on CSR disclosure quality}

Stakeholders are individuals, groups, or organizations who have the same interest in a particular organization [29]. Without the support of stakeholders, the firm cannot run its business properly [30]. Assuming stakeholders have moral responsibilities and the same moral goals, firms must 
demonstrate that they are acting to fulfill the moral responsibilities of stakeholders by disclosing their sustainability activities in sustainability reports [31].[32]. The results also show that the pressure exerted by stakeholders demands high quality sustainability reports [33]. Based on this, the involvement of stakeholders (stakeholder influence) can affect the quality of the firm's CSR disclosure. Based on this description, the following hypothesis can be formulated: hypothesis 2 (H2): Stakeholder Influence has a positive effect on CSR disclosure quality.

\subsubsection{CEO Characteristics, Quality of CSR Disclosure, and Financial Performance}

Upper echelon theory is based on the assumption that "the behavior of business actors is limited rationally. Individual cognitive characteristics and values dominate the decisions of top management members with a major influence on second-tier managers and other employees" [42]. According to this theory, some observable personal attributes can inhibit/trigger the decision-making process, including CSR decisions [8]. In addition, Organizational outcomes derived from strategic decisions and effectiveness are a reflection of leadership characteristics, such as tenure, education, socioeconomic roots, age, functional background, and financial position, which shape the cognitive abilities \& values of leaders [41].

Corporate financial performance plays a key role in improving the quality of strategic decisions and ensuring the successful implementation of innovative strategies, including firm CSR [36], [37], [39], [40], [53]. Previous studies that examined the firm's financial performance showed that the firm's CSR can improve the firm's financial performance [54]-[56]. Based on this description, the following hypotheses can be formulated:

hypothesis 3 (H3a): Financial Performance strengthens the positive influence between CEO Tenure on CSR disclosure quality.

hypothesis 3 (H3b): Financial Performance strengthens the positive effect of CEO Compensation on CSR disclosure quality.

hypothesis 3 (H3c): Financial Performance strengthens the positive effect of CEO Education on CSR disclosure quality.

\subsubsection{Stakeholder Influence, Quality of CSR Disclosure, and Financial Performance}

Stakeholders are individuals, groups, or organizations who have the same interest in a particular organization [29]. Without the support of stakeholders, the firm cannot run its business properly [30]. Assuming stakeholders have moral responsibilities and the same moral goals, firms must demonstrate that they are acting to fulfill the moral responsibilities of stakeholders by disclosing their sustainability activities in sustainability reports [32]. The results also show that the pressure exerted by stakeholders demands high quality sustainability reports [33]. Corporate financial performance plays a key role in improving the quality of strategic decisions and ensuring the successful implementation of innovative strategies, including corporate CSR [36], [37], [39], [40], [53]. Previous studies that examined the firm's financial performance showed that the firm's CSR can improve the firm's financial performance [54]-[56]. Based on this description, the following hypotheses can be formulated:

hypothesis 4 (H4): Financial Performance strengthens the positive influence of Stakeholder Influence on CSR disclosure quality. 
Based on this description, the research model can be described as follows:

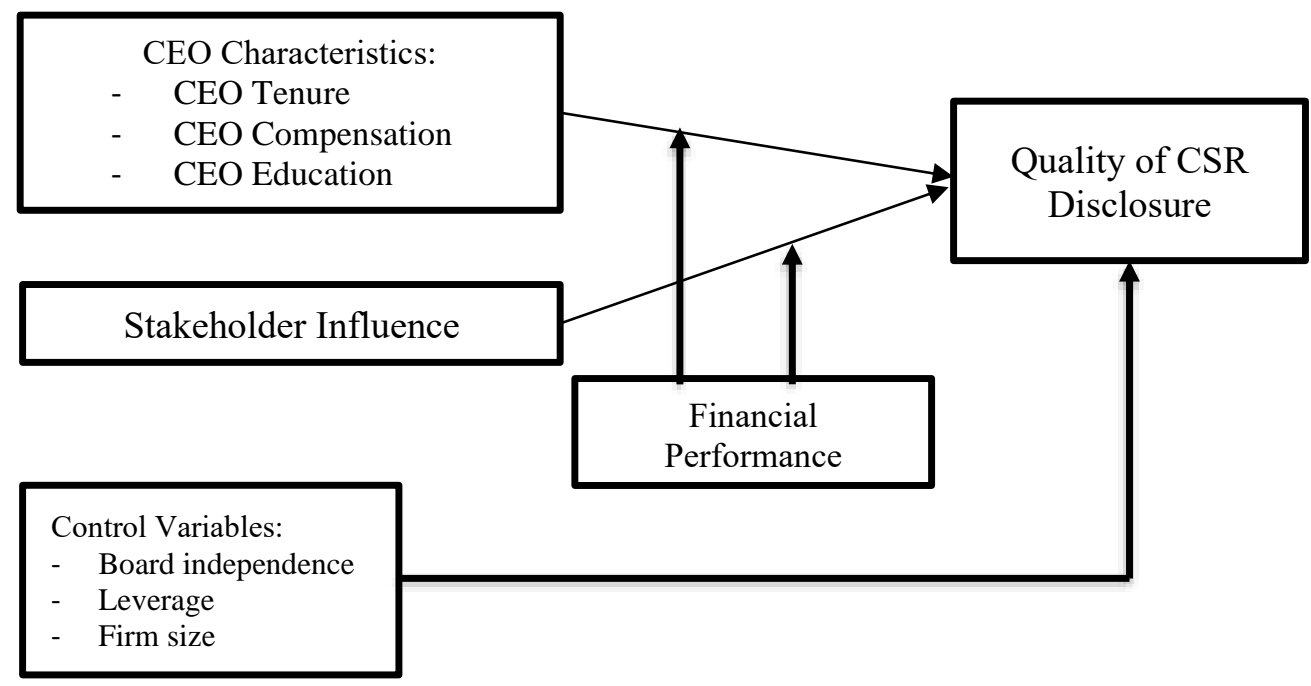

Figure 1. Research Model

\section{Research Method}

This study uses secondary data, i.e., audited financial report data of public firms incorporated in the 2018-2019 Kompas-100 index obtained from the Indonesia Stock Exchange website, as well as CSR report data obtained from the firm website. The data used are audited financial report data and Kompas-100 firm CSR reports in 2018 and 2019, because this period was the period before the economic crisis that occurred due to the COVID-19 pandemic. This is done because this study seeks to test the quality of CSR disclosure, so it is necessary to avoid other factors that can affect the quality of disclosure (for example the COVID-19 pandemic) that may cause bias in research.

\subsection{Operational Variable CSR Disclosure Quality}

CSR disclosure quality is measured using measurement items developed by Habek and Wolniak (2015). Based on Habek and Wolniak (2015), the criteria for measuring relevance consist of 11 items which include: sustainability strategy, stakeholders, reporting objectives, trends from time to time, market performance, workplace, environment, community, corrective actions, integration with business processes, and executive summary. Meanwhile, the criteria for measuring the credibility of information consist of 6 items which include: readability, basic principles of reports, data quality, stakeholder expectations, feedback, and audits. Each CSR report from each firm were assessed for indicators manually and given a ranking using a fivepoint scale (from 1 to 5). Point 1 is awarded when the report does not mention information about the indicator; point 2 if there is some information, but little is mentioned; point 3 if the most important aspects of the indicator are included; point 4 if the report provides better-thanaverage detailed information; and point 5 if the firm explains the indicators completely and in detail. In order to provide a ranking for the two criteria indicators above (relevance and credibility), then from the results of the assessment using a rating scale, the mean of each indicator were calculated as follows: 


$$
\begin{aligned}
& R r=\frac{R 1+R 2+R 3+R 4+R 5+R 6+R 7+R 8+R 9+R 10+R 11}{11} \\
& C c=\frac{C 1+C 2+C 3+C 4+C 5+R 6^{1}}{6}
\end{aligned}
$$

Furthermore, the aggregate quality of the sustainability report indicators for the Sample (Qs) was calculated by:

$Q s=\frac{R r+C c}{2}$

\section{CEO Tenure}

CEO tenure indicates how long a CEO has been in office. Therefore, the length of a CEO's tenure or the length of the contract as CEO is used to determine CEO tenure.

\section{CEO Compensation}

CEO compensation refers to the amount of monetary incentives received by the CEO. Therefore, the amount of CEO compensation paid in a year is used to calculate CEO compensation.

\section{CEO Education}

The previous measurement of CEO education often refers to Huang and Lien (2012), where only CEOs with MS and MBA education backgrounds affect CSR disclosure. However, in recent years there have been many certification bodies related to CSR, such as the NCSR which oversees the CSRS and CSRI certifications. The certification can be obtained even if a person does not have an educational background in economics and business. Based on this, the measurement of CEO education in this study uses a different measurement from previous studies, where this study gives a score of "2" if the CEO has a background in economics and business education and has CSR certification/attended training organized by NCSR, the score " 1 " if the CEO has a background in economics and business education, or the CEO has no economic and business education background but has a CSR certification/attended training organized by NCSR, and a score of " 0 " if the CEO does not have both.

\section{Stakeholder Influence}

Previous studies have shown that stakeholder groups, in particular, primary stakeholders (e.g., consumers, suppliers, financiers, government, and employees) and secondary stakeholders (e.g., media, communities, and non-governmental organizations), can influence the quality of a firm's CSR disclosures [58]. Stakeholder influence is measured using a dummy, where the score is " 1 " is given if the firm has overseas sales, and "0" if it does not. This is based on Rashid et al. (2020), which explains that firms operating in export-oriented industries depend on international buyers for their long-term business survival and growth.

\section{Financial Performance}

There are two well-known financial performance indicators and are often used in various studies, i.e., ROA and Tobin's Q ratio [9]. Financial performance measurement using ROA assesses the financial performance of accounting-based firms, while the Tobin's $Q$ ratio is a market-based performance indicator. The Tobin's $\mathrm{Q}$ ratio takes into account the market value of the firm on the stock exchange. It is often considered a reliable measure that shows a firm's performance based on its growth potential [9]. 


\section{Board independence}

Board independence refers to independent directors who have no affiliation with the firm except for the directorship of the firm. They have an important impact on monitoring activities. Board independence is measured by the number of independent directors on the board relative to the total number of directors [59].

\section{Leverage}

Leverage has been widely suggested as a potential determinant of firm performance, as it helps to overcome agency problems in public firms. We measure financial leverage by debt-to-equity ratio as was done in previous studies [60].

\section{Firm size}

The natural logarithm of total assets is used as a proxy for firm size. This measurement is consistent with research [8].

\section{Results and Discussion}

\section{Instrument Validity and Reliability Test}

The validity test was carried out to determine whether the measuring instrument, which took the form of a questionnaire, could actually perform its function. In addition to being valid, the measuring instrument must also be reliable. The reliability testing uses the Cronbach's Alpha method.

Table 1 The results of the validity and reliability tests of the content of CSR disclosure analysis

\begin{tabular}{ccc}
\hline Items & Coefficient & Notes \\
\hline Item 1 & 0.900 & Valid \\
Item 2 & 0.862 & Valid \\
Item 3 & 0.867 & Valid \\
Item 4 & 0.895 & Valid \\
Item 5 & 0.811 & Valid \\
Item 6 & 0.844 & Valid \\
Item 7 & 0.871 & Valid \\
Item 8 & 0.812 & Valid \\
Item 9 & 0.853 & Valid \\
Item 10 & 0.797 & Valid \\
Item 11 & 0.866 & Valid \\
Item 12 & 0.847 & Valid \\
Item 13 & 0.635 & Valid \\
Item 14 & 0.755 & Valid \\
Item 15 & 0.779 & Valid \\
Item 16 & 0.800 & Valid \\
Item 17 & 0.561 & Valid \\
\hline Cronbach's Alpha Incl. & 0.972 &
\end{tabular}

In table 1, it can be seen that the correlation coefficient ( $r$ ) of each statement item is greater than the critical value of 0.30 . The results of this test indicate that all statement items are valid so 
that they can be included in the next analysis. Cronbach's Alpha coefficient of 0.972 is greater than 0.7. Thus, the question items on the questionnaire are declared reliable.

Table 2 Descriptive Statistics of CEO Education and Stakeholder Influence

\begin{tabular}{lccc}
\hline \multicolumn{1}{c}{ Variable } & Criteria & Freq. & Percentage \\
\hline Stakeholder Influence & Yes & 121 & 69.5 \\
& No & 53 & 30.5 \\
\hline CEO Education & 0 & 51 & 29.3 \\
& 1 & 112 & 64.4 \\
& 2 & 11 & 6.3 \\
\hline
\end{tabular}

Source: processed data (2021)

Table 3 Descriptive Statistics of CEO Tenure, CEO Compensation, Firm's Financial Performance, CSR Quality, and Control Variables

\begin{tabular}{lcrrrr}
\hline \multicolumn{1}{c}{ Variables } & N & \multicolumn{1}{c}{ Mean } & Std. Dev. & \multicolumn{1}{c}{ Min. } & \multicolumn{1}{c}{ Max. } \\
\hline CEO Tenure & 174 & 6.28 & 5.37 & 1.00 & 27.00 \\
Ln CEO Compensation & 174 & 22.23 & 0.82 & 20.42 & 24.27 \\
Tobin's Q & 174 & 8.89 & 64.17 & 0.58 & 659.47 \\
CSRD Quality & 174 & 3.40 & 0.79 & 1.83 & 4.82 \\
Board Independence & 174 & 0.13 & 0.09 & 0.00 & 0.33 \\
Leverage & 174 & 1.82 & 1.87 & 0.12 & 9.26 \\
Firm Size & 174 & 31.03 & 1.56 & 24.86 & 34.89 \\
\hline
\end{tabular}

Source: processed data (2021)

In table 2, it can be seen that CEO education has the highest score for a score of 1 , where the CEO has a background in economics and business education, or the CEO does not have an economic and business education background, but has CSR certification. Thus, $70 \%$ of CEO education in this study has economic and business education background, or CEO does not have economic and business education background, but has CSR certification, or even has both economic and business education background and is also CSR certified. The descriptive statistics in table 3 show that the CEO Tenure variable and the firm's financial performance have a relatively high standard deviation value compared to the mean value. This shows that the variability of the sample for CEO Tenure and the Firm's Financial Performance is quite high. Meanwhile, the variables of CEO compensation, CSRD quality, board independence, leverage, and firm size have a lower standard deviation than the mean value. This shows that CEO compensation, CSRD quality, board independence, leverage, and firm size in the sample of this study are homogeneous and have low variability.

On the other hand, the average CEO tenure is 6.28 years with a minimum of 1 year and a maximum of 27 years. CEO compensation shows a natural logarithm average of 22.23 with a minimum of 20.42 and a maximum of 24.27. The firm's financial performance as measured by Tobin's Q shows an average of $8.89 \%$, with a minimum of $0.58 \%$ and a maximum of $659.47 \%$. 


\section{Classic assumption test}

There are several assumptions that must be made before testing the hypothesis using moderated regression analysis, including the normality test using the Kolmogorov-Smirnov test, and the regression model is said to be normally distributed if the probability value (significance) is greater than 0.05. The results of this study's normality test revealed a significance value (Asymp.sig.2-tailed) obtained from the Kolmogorov-Smirnov test of 0.200 $>0.05$, indicating that the regression model was normally distributed. In the heteroscedasticity test, the Glejser test is used. If there is a significant regression coefficient at an error rate of 5\%, it indicates the occurrence of heteroscedasticity. The significance value of the regression coefficient of each independent variable is still greater than 0.05 . This indicates that the independent variable has no relationship with the absolute residual. Thus, it can be concluded that there are no symptoms of heteroscedasticity in the regression model. The results of the multicollinearity test are indicated by the VIF value $<10$. This indicates that there is no multicollinearity between the variables in this study.

\section{Correlation Analysis}

Before testing the effect of CEO characteristics moderated by corporate financial performance on CSR disclosure quality, the relationship between CEO characteristics and CSR disclosure quality is analyzed first.

\section{Table 4 Correlation Matrix}

\begin{tabular}{|c|c|c|c|c|c|c|c|c|c|c|c|c|c|}
\hline & & CSRD & Ten & Conte & Edu & SI & FP & Ten'FP & ComperpP & Edu ${ }^{*} \mathrm{FP}$ & SI'FP Ind & Lev & Size \\
\hline 1 & $Y$ & 1 & & & & & & & & & & & \\
\hline 2 & $x_{1}$ & $0.130^{\circ}$ & 1 & & & & & & & & & & \\
\hline 3 & $x_{2}$ & 0.082 & $0.125^{\circ}$ & 1 & & & & & & & & & \\
\hline 4 & $x_{3}$ & $0.235^{*}$ & $-0.212^{\circ}$ & 0.009 & 1 & & & & & & & & \\
\hline 5 & $x 4$ & $0.421^{\circ}$ & $0.139^{\circ}$ & 0.069 & -0.072 & 1 & & & & & & & \\
\hline 6 & M & 0.022 & -0.002 & 0.080 & 0.046 & -0.052 & 1 & & & & & & \\
\hline 7 & $\mathrm{XI}_{1} \mathrm{M}$ & 0.041 & $-0.180^{\circ}$ & -0.087 & 0.039 & 0.080 & -0.114 & 1 & & & & & \\
\hline 8 & $\mathrm{X} 2^{*} \mathrm{M}$ & 0.059 & -0.046 & -0.037 & 0.038 & -0.116 & $0.843^{\circ}$ & $-0.593^{\circ}$ & 1 & & & & \\
\hline 9 & $\times 3^{\circ} \mathrm{M}$ & 0.080 & 0.043 & 0.079 & $-0.222^{\circ}$ & -0.034 & $0.963^{\circ}$ & -0.120 & $0.812^{*}$ & 1 & & & \\
\hline 10 & $\mathrm{X}^{4} \mathrm{M}$ & 0.001 & 0.025 & 0.013 & 0.040 & -0.025 & $0.634^{\circ}$ & $0.668^{\circ}$ & $0.135^{*}$ & $0.605^{\circ}$ & 1 & & \\
\hline 11 & $X 5$ & $-0.151^{*}$ & 0.083 & $0.229^{\circ}$ & 0.085 & $-0.155^{\circ}$ & $0.156^{\circ}$ & -0.098 & $0.137^{*}$ & $0.130^{\circ}$ & 0.060 & & \\
\hline 12 & $x_{6}$ & $0.312^{*}$ & -0.111 & 0.006 & $0.128^{\circ}$ & -0.029 & -0.045 & 0.006 & -0.075 & -0.074 & $0.0160 .235^{\circ}$ & 1 & \\
\hline 13 & $\times 7$ & $0.397^{\circ}$ & $-0.166^{*}$ & 0.028 & 0.100 & 0.119 & $-0.259^{\circ}$ & -0.112 & $-0.125^{*}$ & -0.277 & $-0.315^{*} 0.386^{*}$ & $0.476^{*}$ & 1 \\
\hline
\end{tabular}

Source: processed data (2021) 


\section{Hypotheses Test Result}

The moderating regression equation model was used to examine the effect of CEO characteristics and stakeholder influence moderated by the firm's financial performance on CSR disclosure quality with board independence, leverage, and firm age as control variables.

Table 5 Results of Moderating Regression Analysis

\begin{tabular}{|c|c|c|c|c|c|c|c|}
\hline \multirow{2}{*}{ Variables } & \multicolumn{2}{|c|}{ Model 1} & \multicolumn{2}{|c|}{ Model 2} & \multicolumn{2}{|c|}{ Model 3} & \multirow{2}{*}{$\begin{array}{c}\text { Hypotheses } \\
\text { status }\end{array}$} \\
\hline & Coeff. & Sig. & Coeff. & Sig. & Coeff. & Sig. & \\
\hline CEO Tenure $\left(\mathrm{X}_{1}\right)$ & 0.019 & 0.060 & 0.085 & 0.000 & 0.087 & 0.000 & \multirow{4}{*}{$\begin{array}{c}\text { H1 supported } \\
\text { H2 not-supported } \\
\text { H3 supported } \\
\text { H4 supported }\end{array}$} \\
\hline CEO Compensation $\left(\mathrm{X}_{2}\right)$ & 0.033 & 0.614 & 0.672 & 0.037 & 0.391 & 0.182 & \\
\hline CEO Education $\left(\mathrm{X}_{3}\right)$ & 0.420 & 0.000 & 2.083 & 0.003 & 2.046 & 0.002 & \\
\hline Stakeholder Influence $\left(\mathrm{X}_{4}\right)$ & 0.726 & 0.000 & 0.970 & 0.000 & 0.732 & 0.002 & \\
\hline Tobin's Q (M) & & & 0.115 & 0.003 & 0.085 & 0.017 & \multirow{5}{*}{$\begin{array}{c}\text { Sig } \\
\text { H5 supported } \\
\text { H6 not-supported } \\
\text { H7 supported } \\
\text { H8 not-supported }\end{array}$} \\
\hline CEO Tenure ${ }^{*} \mathrm{M}$ & & & 2.867 & 0.004 & 2.480 & 0.006 & \\
\hline CEO Compensation*M & & & 4.627 & 0.039 & 2.791 & 0.171 & \\
\hline CEO Education $* \mathrm{M}$ & & & 7.943 & 0.017 & 8.012 & 0.010 & \\
\hline Stakeholder Influence*M & & & 1.780 & 0.361 & 0.454 & 0.798 & \\
\hline Board Independence $\left(\mathrm{X}_{5}\right)$ & & & & & -0.249 & 0.672 & Not-sig \\
\hline Leverage $\left(\mathrm{x}_{6}\right)$ & & & & & 0.060 & 0.039 & Sig \\
\hline Firm Size $\left(\mathrm{X}_{7}\right)$ & & & & & 0.150 & 0.000 & sig \\
\hline R Square & \multicolumn{2}{|c|}{0.266} & \multicolumn{2}{|c|}{0.334} & \multicolumn{2}{|c|}{0.469} & \\
\hline Adjusted R Square & \multicolumn{2}{|c|}{0.249} & \multicolumn{2}{|c|}{0.298} & \multicolumn{2}{|c|}{0.430} & \\
\hline F (sig.) & \multicolumn{2}{|c|}{$\begin{array}{l}15.322 \\
(0.000)\end{array}$} & \multicolumn{2}{|c|}{$9.149(0.000)$} & \multicolumn{2}{|c|}{$\begin{array}{l}11.871 \\
(0.000)\end{array}$} & \\
\hline
\end{tabular}

Source: processed data (2021)

In table 5, it can be seen in model 1 that the coefficient of determination (R Square) of 0.249 indicates that the characteristics of CEO and stakeholder influence without moderating variables and control variables are able to explain the variance of CSR disclosure quality of $24.9 \%$. Then, in model 2 with the inclusion of the firm's financial performance as a moderating variable, it is obtained $\mathrm{R}$ Square of 0.298 . This means that with the inclusion of the firm's financial performance as a moderating variable, the characteristics of the CEO and stakeholder influence are able to explain the variance in the quality of CSR disclosure of $29.8 \%$. Then, in model 3 with the existence of board independence, leverage, and firm size as control variables, the R Square of 0.43 is obtained. This means that with the existence of board independence, leverage, and firm size as control variables, CEO characteristics and stakeholder influence moderated by the firm's financial performance are able to explain the variance in the quality of CSR disclosure by $43 \%$. The $\mathrm{F}$ value in model 3 is 11.871 with a probability value less than 0.05. This indicates that the characteristics of CEO and stakeholder influence moderated by firm financial performance with board independence, leverage, and firm size as control variables can be used to predict the quality of CSR disclosure.

In table 5 model 3, it can be seen that CEO tenure, CEO Education, and Stakeholder Influence has a positive coefficient on CSR disclosure quality with each probability value of (0.000; 0.002; 0.002). Thus, it can be concluded that CEO tenure, CEO Education, and Stakeholder Influence can increase CSR disclosure quality. In table 5 model 3, it can be seen that CEO compensation has a positive coefficient on CSR disclosure quality with a probability value of 0.182. the result show that CEO compensation has no effect on CSR disclosure quality. CEO tenure \& CEO Education moderated by the firm's financial performance has a positive coefficient on CSR disclosure quality with each probability value of $0.006 \& 0.01$. Thus, it can 
be concluded that CEO tenure \& CEO Education which is moderated by the firm's financial performance has a positive effect on CSR disclosure quality, but not for CEO compensation and stakeholder influence which have probability value of $0.171 \& 0.798$.

\subsection{Discussion}

This research has successfully proven that CEO characteristic named CEO tenure and CEO education has a significant positive effect on CSR disclosure quality. The results of this study support the results of previous studies which show that there is a positive influence between CEO tenure and CSR disclosure [8], [52]. Thus, more experienced CEOs tend to be more aware of CSR practices and disclosures whether they are for legitimate purposes or perhaps to support a stakeholder perspective. The results of this study also support the results of previous studies [22], [52], where a highly educated CEO has been shown to affect the firm's CSR performance. Increased CEO education (e.g., with a master's or $\mathrm{PhD}$ degree, particularly in a CSR-related discipline) is also associated with increased reliance on stakeholder demands and CSR activities. The results of this study also prove that CEOs who have CSR-related certifications can improve the quality of the firm's CSR disclosures. Thus, the results of this study support the upper echelon theory, where individual values $\&$ cognitive characteristics dominate the decisions of top management members with a major influence on other employees [42].

However, this study did not successfully prove the effect of CEO compensation on CSR disclosure quality. The results of this study are in line with Fredrik and Johansson (2018) study. This may be due to the difference in the amount of CEO compensation in Rupiah and in US Dollars, which are very far apart. However, in the data used in this study, more CEO compensation is paid in Rupiah, so the amount is not too large. The lowest CEO compensation is Rp900 million, and the highest is Rp26 billion, while the average CEO compensation is Rp3 billion. These results indicate that the average CEO compensation used in this study has a wide range. The difference in CEO compensation payments can trigger the high (low) quality of the firm's CSR disclosures.

This research show that stakeholder influence has a significant positive effect on CSR disclosure quality. The results of this study are in line with [33], where the pressure exerted by stakeholders demands high quality sustainability reports. The results of this study also support the theory of legitimacy, where firms must act in accordance with the value system prevailing in society. Assuming stakeholders have moral responsibilities and the same moral goals, firms must demonstrate that they are acting to fulfill the moral responsibilities of stakeholders by disclosing their sustainability activities in sustainability reports [32].

Furthermore, this research has successfully proven that financial performance moderate positive influence between CEO characteristic named CEO tenure and CEO education to CSR disclosure quality. Organizational outcomes derived from strategic decisions and effectiveness are a reflection of leadership characteristics, such as tenure, educatiaon, socioeconomic roots, age, functional background, and financial position, which shape the values and cognitive abilities of leaders [41]. Corporate financial performance plays a key role in improving the quality of strategic decisions and ensuring the successful implementation of innovative strategies, including corporate CSR [37], [40], [53]. Previous studies that examined the firm's financial performance showed that the firm's CSR can improve the firm's financial performance [56]-[58].[54]-[56]. However, the results of this study fail to show that the firm's financial performance is able to moderate the effect of CEO compensation on CSR disclosure quality. This is because before the moderation test, there is no influence between CEO compensation on CSR disclosure quality, which may be due to the wide compensation range between firms 
with compensation in Rupiah and compensation in USD. The results show that the firm's financial performance did not succeed in moderating the influence of stakeholder influence on CSR disclosure quality. This may be due to the very weak correlation between stakeholder influence and financial performance on CSR disclosure quality. Thus, the results of this study are not able to support [17].

\section{Conclusions, Implications, and Limitations}

This study aims to examine whether the CEO characteristics consisting of CEO tenure, CEO compensation, and CEO education, as well as stakeholder involvement affect the quality of the firm's CSR disclosures. Furthermore, this study also examines whether the firm's financial performance can moderate the effect of CEO characteristics and stakeholder involvement on firms' CSR disclosure quality. The results of this study indicate that CEO tenure, CEO education, and stakeholder involvement have a significant positive effect on CSR disclosure quality. However, CEO compensation has no effect on CSR disclosure quality. Furthermore, the firm's financial performance was proven to moderate the positive influence between CEO tenure and CEO education on the quality of the firm's CSR disclosure, but failed to moderate the effect of CEO compensation and stakeholder involvement on the quality of the firm's CSR disclosure.

The results of our study related to CEO characteristics have practical implications for firms and regulators, especially regarding CEO education, where the role of CEO education and certification in the field of CSR can improve the quality of firms' CSR disclosure. The government and professional institutions (IAI, IAPI) are deemed necessary to establish certain educational and certification standards for firm management and auditors in order to improve CSR disclosure quality, particularly in integrated reports. Furthermore, the results of this study also convey a message to regulators and other stakeholders that the influence of stakeholders plays a role in limiting the opportunistic attitudes of firm CEOs regarding CSR disclosure.

Apart from the implications of the results of this study, this study also has limitations, especially regarding the characteristics of CEOs. In an effort to test the upper echelon theory, further research needs to explore various CEO characteristics that are important in improving the quality of CSR disclosure, such as CEO age, CEO turnover rate, CEO power, CEO narcissism, and CEO value.

\section{References}

[1] KPMG, "The road ahead - The KPMG survey of corporate responsibility reporting 2017," road ahead - KPMG Surv. Corp. Responsib. Report. 2017, pp. 1-58, 2017, doi: 10.1038/nnano.2013.238.

[2] H. Haris Astuti, R. Aron Oktavianus, Y. Augustine, "The Effect Of Corporate Social Responsibility Disclosure And Performance On Company Value With Industry Type As A Moderating Variable," J. Magister Akuntansi Trisakti, vol. 5, no. 2, pp. 185-202, 2018, doi: 10.25105/jmat.v5i2.5074.

[3] A. R. Belal and S. Cooper, "The absence of corporate social responsibility reporting in Bangladesh," Crit. Perspect. Account., vol. 22, no. 7, pp. 654-667, Oct. 2011, doi: 10.1016/j.cpa.2010.06.020.

[4] U. Golob and J. L. Bartlett, "Communicating about corporate social responsibility: A comparative study of CSR reporting in Australia and Slovenia," Public Relat. Rev., vol. 33, no. 1, pp. 1-9, Mar. 2007, doi: 10.1016/j.pubrev.2006.11.001. 
[5] C. A. Adams, "Internal organisational factors influencing corporate social and ethical reporting: Beyond current theorising," Accounting, Auditing \& Accountability Journal, vol. 15, no. 2. MCB UP Ltd, pp. 223-250, May 01, 2002, doi: $10.1108 / 09513570210418905$.

[6] A. Baele and P. Everaert, "The CEO's perception on CSR: a determinant of CSR reporting," 2012. Accessed: Sep. 24, 2020. [Online]. Available: https://lib.ugent.be/fulltxt/RUG01/001/893/406/RUG01001893406_2012_0001_AC.pdf.

[7] M. B. Abu Qa'dan and M. S. Suwaidan, "Board composition, ownership structure and corporate social responsibility disclosure: the case of Jordan," Soc. Responsib. J., vol. 15, no. 1, pp. 28-46, 2019, doi: 10.1108/SRJ-11-2017-0225.

[8] F. Malik, F. Wang, M. A. Naseem, A. Ikram, and S. Ali, "Determinants of Corporate Social Responsibility Related to CEO Attributes: An Empirical Study," SAGE Open, vol. 10, no. 1, 2020, doi: 10.1177/2158244019899093.

[9] A. Dakhli, "Does financial performance moderate the relationship between board attributes and corporate social responsibility in French firms?," J. Glob. Responsib., vol. 12, no. 4, pp. 373-399, 2021, doi: 10.1108/jgr-02-2021-0016.

[10] Nurulyasmin, Binti Ju Ahmad, Afzalur, Rashid, and J. Gow, "CEO Duality and Corporate Social Responsibility Reporting: Evidence from Malaysia," Corp. Ownersh. Control, vol. 14, no. 2, pp. 69-81, 2017.

[11] H. S. T. Pham and H. T. Tran, "CSR disclosure and firm performance: The mediating role of corporate reputation and moderating role of CEO integrity," J. Bus. Res., vol. 120, no. January 2019, pp. 127-136, 2020, doi: 10.1016/j.jbusres.2020.08.002.

[12] S. D. D. Sundarasen, T. Je-Yen, and N. Rajangam, "Board composition and corporate social responsibility in an emerging market," Corp. Gov., vol. 16, no. 1, pp. 35-53, Feb. 2016, doi: 10.1108/CG-05-2015-0059.

[13] S. Deschênes, M. Rojas, H. Boubacar, B. Prud'homme, and A. Ouedraogo, "The impact of board traits on the social performance of Canadian firms," Corp. Gov., vol. 15, no. 3, pp. 293-305, Jun. 2015, doi: 10.1108/CG-08-2014-0097.

[14] J. Kang, "Unobservable CEO Characteristics and CEO Compensation as Correlated Determinants of CSP,” Bus. Soc., vol. 56, no. 3, pp. 419-453, Mar. 2017, doi: 10.1177/0007650314568862.

[15] M. B. Muttakin and N. Subramaniam, "Firm ownership and board characteristics: Do they matter for corporate social responsibility disclosure of Indian Companies?," Sustain. Accounting, Manag. Policy J., vol. 6, no. 2, pp. 138-165, May 2015, doi: 10.1108/SAMPJ-10-2013-0042.

[16] M. B. Muttakin, A. Khan, and D. G. Mihret, "The Effect of Board Capital and CEO Power on Corporate Social Responsibility Disclosures," J. Bus. Ethics, vol. 150, no. 1, pp. 41-56, 2018, doi: 10.1007/s10551-016-3105-y.

[17] A. Rashid, S. Shams, S. Bose, and H. Khan, CEO power and corporate social responsibility (CSR) disclosure: does stakeholder influence matter? 2020.

[18] M. Jian and K. W. Lee, "CEO compensation and corporate social responsibility," J. Multinatl. Financ. Manag., vol. 29, pp. 46-65, Feb. 2015, doi: 10.1016/J.MULFIN.2014.11.004.

[19] S. A. C. Rekker, K. L. Benson, and R. W. Faff, "Corporate social responsibility and CEO compensation revisited: Do disaggregation, market stress, gender matter?," $J$. Econ. Bus., vol. 72, pp. 84-103, Mar. 2014, doi: 10.1016/J.JECONBUS.2013.11.001.

[20] S. K. Huang, "The Impact of CEO Characteristics on Corporate Sustainable 
Development," Corp. Soc. Responsib. Environ. Manag., vol. 20, no. 4, pp. 234-244, Jul. 2013, doi: 10.1002/csr.1295.

[21] W. (Tina) Chen, G. (Stephen) Zhou, and X. (Kevin) Zhu, "CEO tenure and corporate social responsibility performance," J. Bus. Res., vol. 95, pp. 292-302, Feb. 2019, doi: 10.1016/J.JBUSRES.2018.08.018.

[22] B. W. Lewis, J. L. Walls, and G. W. S. Dowell, "Difference in degrees: CEO characteristics and firm environmental disclosure," Strateg. Manag. J., vol. 35, no. 5, pp. 712-722, May 2014, doi: 10.1002/SMJ.2127.

[23] W. Y. Oh, Y. K. Chang, and R. Jung, "Experience-based human capital or fixed paradigm problem? CEO tenure, contextual influences, and corporate social (ir)responsibility," J. Bus. Res., vol. 90, pp. 325-333, Sep. 2018, doi: 10.1016/J.JBUSRES.2018.05.034.

[24] li Sun and F. Rakhman, "CFO financial expertise and corporate social responsibility: Evidence from S\&P 500 companies," Int. J. Law Manag., vol. 55, no. 3, pp. 161-172, May 2013, doi: 10.1108/17542431311327619/FULL/XML.

[25] Y. Li, M. Gong, X. Y. Zhang, and L. Koh, "The impact of environmental, social, and governance disclosure on firm value: The role of CEO power," Br. Account. Rev., vol. 50, no. 1, pp. 60-75, Jan. 2018, doi: 10.1016/J.BAR.2017.09.007.

[26] N. Katmon, Z. Z. Mohamad, N. M. Norwani, and O. Al Farooque, "Comprehensive Board Diversity and Quality of Corporate Social Responsibility Disclosure: Evidence from an Emerging Market," J. Bus. Ethics, vol. 157, no. 2, pp. 447-481, 2019, doi: 10.1007/s10551-017-3672-6.

[27] W. Chapple and J. Moon, "Corporate Social Responsibility (CSR) in Asia," Bus. Soc., vol. 44, no. 4, pp. 415-441, Dec. 2005, doi: 10.1177/0007650305281658.

[28] I. Lock and P. Seele, "The credibility of CSR (corporate social responsibility) reports in Europe. Evidence from a quantitative content analysis in 11 countries," J. Clean. Prod., vol. 122, pp. 186-200, May 2016, doi: 10.1016/j.jclepro.2016.02.060.

[29] B. T. Lamont, "Book Review:," https://doi.org/10.2307/4131462, vol. 49, no. 1, pp. 145-147, Jun. 2016, doi: 10.2307/4131462.

[30] B. Fernandez-Feijoo, S. Romero, and S. Ruiz, "Effect of Stakeholders' Pressure on Transparency of Sustainability Reports within the GRI Framework," J. Bus. Ethics 2013 1221, vol. 122, no. 1, pp. 53-63, May 2013, doi: 10.1007/S10551-013-1748-5.

[31] H. Kurniawati and Y. A. Sudibyo, "Disclosure of Corporate Social Responsibility and Economic Value Added: The Moderating Role of Family Ownership and CSR Award," J. Keuang. dan Perbank., vol. 14, no. 1, pp. 29-36, 2017.

[32] A. Rudyanto and S. V. Siregar, "The effect of stakeholder pressure and corporate governance on the sustainability report quality," Int. J. Ethics Syst., vol. 34, no. 2, pp. 233-249, 2018, doi: 10.1108/IJOES-05-2017-0071/FULL/XML.

[33] M. S. Sampaio, S. M. da S. Gomes, A. L. Bruni, and J. M. D. Filho, "Evidence Of Social And Environmental Information And Isomorphism: A Study With Brazilian Mining Companies," Rev. Universo Contábil, vol. 8, no. 1, pp. 105-122, Jan. 2012, doi: 10.4270/RUC.20128.

[34] Y. K. Chang, W. Y. Oh, J. H. Park, and M. G. Jang, "Exploring the Relationship Between Board Characteristics and CSR: Empirical Evidence from Korea," J. Bus. Ethics 2015 1402, vol. 140, no. 2, pp. 225-242, Apr. 2015, doi: 10.1007/S10551-0152651-Z.

[35] R. Aggarwal and R. G. Williamson, "Did New Regulations Target the Relevant Corporate Governance Attributes?," SSRN Electron. J., Feb. 2006, doi: 


\subsection{9/SSRN.859264.}

[36] M. Muafi, Y. Siswanti, A. K. Diharto, and I. Salsabil, "Innovation Culture and Process in Mediating Human Capital Supply Chain on Firm Performance," J. Asian Financ. Econ. Bus., vol. 7, no. 9, pp. 593-602, 2020, doi: 10.13106/JAFEB.2020.VOL7.NO9.593.

[37] M. Javed, M. A. Rashid, G. Hussain, and H. Y. Ali, "The effects of corporate social responsibility on corporate reputation and firm financial performance: Moderating role of responsible leadership," Corp. Soc. Responsib. Environ. Manag., vol. 27, no. 3, pp. 1395-1409, May 2020, doi: 10.1002/CSR.1892.

[38] Y. Liu, M. K. Miletkov, Z. Wei, and T. Yang, "Board independence and firm performance in China," J. Corp. Financ., vol. 30, pp. 223-244, Feb. 2015, doi: 10.1016/j.jcorpfin.2014.12.004.

[39] S. J. Cho, C. Y. Chung, and J. Young, "Study on the Relationship between CSR and Financial Performance," Sustain. 2019, Vol. 11, Page 343, vol. 11, no. 2, p. 343, Jan. 2019, doi: 10.3390/SU11020343.

[40] S. Franco, M. G. Caroli, F. Cappa, and G. Del Chiappa, "Are you good enough? CSR, quality management and corporate financial performance in the hospitality industry," Int. J. Hosp. Manag., vol. 88, Jul. 2020, doi: 10.1016/J.IJHM.2019.102395.

[41] D. C. Hambrick and P. A. Mason, "Upper Echelons: The Organization as a Reflection of Its Top Managers," Acad. Manag. Rev., vol. 9, no. 2, p. 193, Apr. 1984, doi: $10.2307 / 258434$.

[42] P. Velte, "Do CEO incentives and characteristics influence corporate social responsibility (CSR) and vice versa? A literature review," Soc. Responsib. J., vol. 16, no. 8, pp. 1293-1323, Oct. 2019, doi: 10.1108/SRJ-04-2019-0145.

[43] S. J. Callan and J. M. Thomas, "Executive compensation, corporate social responsibility, and corporate financial performance: a multi-equation framework," Corp. Soc. Responsib. Environ. Manag., vol. 18, no. 6, pp. 332-351, Nov. 2011, doi: $10.1002 / \mathrm{csr} .249$.

[44] S. J. Callan and J. M. Thomas, "Relating CEO Compensation to Social Performance and Financial Performance: Does the Measure of Compensation Matter?," Corp. Soc. Responsib. Environ. Manag., vol. 21, no. 4, pp. 202-227, Jul. 2014, doi: 10.1002/csr.1307.

[45] R. Gray, R. Kouhy, and S. Lavers, "Corporate social and environmental reporting A review of the literature and a longitudinal study of UK disclosure," Accounting, Audit. Account. J., vol. 8, no. 2, pp. 47-77, 1995, doi: 10.1108/09513579510146996.

[46] C. Deegan, Introduction: The legitimising effect of social and environmental disclosures - a theoretical foundation, vol. 15, no. 3. 2002.

[47] J. N. Chauvey, S. Giordano-Spring, C. H. Cho, and D. M. Patten, "The Normativity and Legitimacy of CSR Disclosure: Evidence from France," J. Bus. Ethics, vol. 130, no. 4, pp. 789-803, 2015, doi: 10.1007/s10551-014-2114-y.

[48] G. Michelon, S. Pilonato, and F. Ricceri, "CSR reporting practices and the quality of disclosure: An empirical analysis," Crit. Perspect. Account., vol. 33, pp. 59-78, Dec. 2015, doi: 10.1016/j.cpa.2014.10.003.

[49] P. Hąbek and R. Wolniak, "Assessing the quality of corporate social responsibility reports: the case of reporting practices in selected European Union member states," Qual. Quant., vol. 50, no. 1, pp. 399-420, 2016, doi: 10.1007/s11135-014-0155-z.

[50] S. L. Hart, "A Natural-Resource-Based View of the Firm," Acad. Manag. Rev., vol. 20, no. 4, p. 986, Oct. 1995, doi: 10.2307/258963. 
[51] I. F. Kesner, "Directors' Characteristics And Committee Membership: An Investigation Of Type, Occupation, Tenure, And Gender.," Acad. Manag. J., vol. 31, no. 1, pp. 6684, Mar. 1988, doi: 10.2307/256498.

[52] C. F. Huang and H. C. Lien, "An empirical analysis of the influences of corporate social responsibility on organizational performance of Taiwan's construction industry: Using corporate image as a mediator," Constr. Manag. Econ., vol. 30, no. 4, pp. 263275, Apr. 2012, doi: 10.1080/01446193.2012.668620.

[53] Y. Liu, L. Lei, and E. H. Buttner, "Establishing the boundary conditions for female board directors' influence on firm performance through CSR," J. Bus. Res., vol. 121, pp. 112-120, Dec. 2020, doi: 10.1016/J.JBUSRES.2020.08.026.

[54] P. Jain, V. Vyas, and D. P. S. Chalasani, "Corporate Social Responsibility and Financial Performance in SMEs: A Structural Equation Modelling Approach," Glob. Bus. Rev., vol. 17, no. 3, pp. 630-653, Jun. 2016, doi: 10.1177/0972150916630827.

[55] B. Khan and R. Tariq, "Corporate Social Responsibility Impact on Financial Performance of Islamic and Conventional Banks: Evidence from Asian Countries," Online, 2017. Accessed: Jan. 26, 2021. [Online]. Available: www.iiste.org.

[56] M. Ramzan, M. Amin, and M. Abbas, "How does corporate social responsibility affect financial performance, financial stability, and financial inclusion in the banking sector? Evidence from Pakistan," Res. Int. Bus. Financ., vol. 55, Jan. 2021, doi: 10.1016/j.ribaf.2020.101314.

[57] P. Habek and R. Wolniak, "Factors influencing the development of CSR reporting practices: Experts' versus preparers' points of view," Eng. Econ., vol. 26, no. 5, pp. 560-570, 2015, doi: 10.5755/j01.ee.26.5.7690.

[58] S. Bose, H. Z. Khan, A. Rashid, and S. Islam, "What drives green banking disclosure? An institutional and corporate governance perspective," Asia Pacific J. Manag., vol. 35, no. 2, pp. 501-527, Jun. 2018, doi: 10.1007/S10490-017-9528-X/TABLES/6.

[59] S. Das, J. J. Gong, and S. Li, "The Effects of Accounting Expertise of Board Committees on the Short- and Long-Term Consequences of Financial Restatements," $J$. Accounting, Audit. Financ., 2020, doi: 10.1177/0148558X20934943.

[60] H. S. T. Pham and H. T. Tran, "CSR disclosure and firm performance: The mediating role of corporate reputation and moderating role of CEO integrity," J. Bus. Res., vol. 120, pp. 127-136, Nov. 2020, doi: 10.1016/j.jbusres.2020.08.002.

[61] A. A. Fredrik and H. Johansson, "Corporate Social Responsibility, Corporate Governance and CEO compensation incentives," 2018. 